\title{
THE EFFECT OF THE EXTREME TEMPERATURE OF DEC. 7, 8, AND 9, 1927 ON HIBERNATING CRIOCERIS ASPARAGI L. AND HIPPODAMIA CONVERGENS GUER. AT AMES, IOWA
}

\author{
By Randall Latta \\ Ames, Iowa
}

During the early winter of 1927 at Ames, Iowa, the temperature dropped suddenly on Dec. 6 from $26^{\circ} \mathrm{F}$ to $7^{\circ}$ the following day, to $-25^{\circ}$ on the 8 th and then rose again to $-8^{\circ}$ on the 9th. A small amount of snow had previously fallen, but was mostly in drifts, leaving many places exposed.

Field observations following this period proved that Hippodamia convergens Guer., a common coccinellid and Crioceris asparagi $\mathrm{L}$. the asparagus beetle, were not able to withstand this unusual temperature.

Hippodamia convergens is probably the most common coccinellid in the vicinity of Ames, Iowa. Large numbers of them, as well as lesser quantities of other species of ladybirds, gathered in late summer at a turnip patch on a truck farm at the outskirts of Ames, to feed on the aphids there. As fall advanced the beetles hibernated in the sod fencerow at the edge of the turnip field.

In the latter part of December the above mentioned fencerow was examined and a $100 \%$ mortality found. In a space 6 feet long and one foot wide immediately bordering the turnip patch 26 dead $H$. convergens were counted. An open crevice of a fencepost held 50 dead ladybirds of this species, and between 50 and 75 dead specimens were removed from beneath a stone at the same place. At the same time living specimens of $H$. parenthesis, H. 13-punctata and Coccinella 9-notata were found active among the dead $H$. convergens.

Other observations made later supported the above findings. At a highland prairie northwest of Gilbert, Iowa, nearly 40 dead $H$. convergens were uncovered beneath stones, and at the time living $H$. 13-punctata and $H$. parenthesis were collected.

In the spring of 1928, Hippodamia 13-punctata and H. pa- 
renthesis were very common while $H$. convergens were scarce enough to be almost rare.

At the same truck farm, a large asparagus bed was heavily invested with Crioceris asparagi. These beetles hibernated early in such shelter as they could find: in the sod of the fencerows, hollow asparagus stalks thruout the bed, hollow weed stalks, in the burrows of the grape cane borer, smartweed borer, and even in company with a strawberry leaf roller larva in a folded strawberry leaf.

After Dec. 10th an exhaustive survey of the asparagus bed revealed an almost total mortality, only six beetles being revived when warmed out of several hundred collected. The six were hibernating in a hollow asparagus stalk.

In the sod fencerow the beetles had hidden in the layers of decayed organic material found at the surface of the ground in most blue grass sod, but were never found in the ground. The first 12 or 14 inches of sod next to the asparagus sheltered the majority of the beetles that had thus wintered. As high as 83 specimens were counted in an area one foot square.

The asparagus beetles had not been observed to bore into a stalk, nor had any evidences of frass been seen in the stalks examined. Beetles had entered, usually, by the path of some previous insect, or at a broken internode.

A number of stalks in lots of 50 were examined to determine the number of beetles that had used such shelter, and in four lots the infestation ran $32 \%, 32 \%, 22 \%$, and $52 \%$ with as high as 46 specimens in a single stalk.

Two species of Anthicide, Anthicus cervinus Laf. and $A$. amœnus Casey, were often collected in company with the asparagus beetles and always showed activity upon being disturbed.

Sanderson (Journal of Economic Entomology, Vol. I, 1908, pp. 245-262) plots on a map of the United States a series of isotherms showing the average annual-minimum temperatures and the relation between the northward limitation of certain forms and these isotherms. The average annual-minimum for central Iowa is $-10^{\circ}$. The $-25^{\circ}$ of the past winter is therefore an exceptional drop for this locality. 
The average annual minimum isotherm of $-10^{\circ}$ bisects Iowa, crosses northern Illinois, cuts thru Michigan and includes the region of Ontario influenced by the lakes, cuts thru New York state and the center of New England. Allowing for seasonal deviations of warm winters, ete., the beetle has hovered along this invisible barrier during its westward spread. 

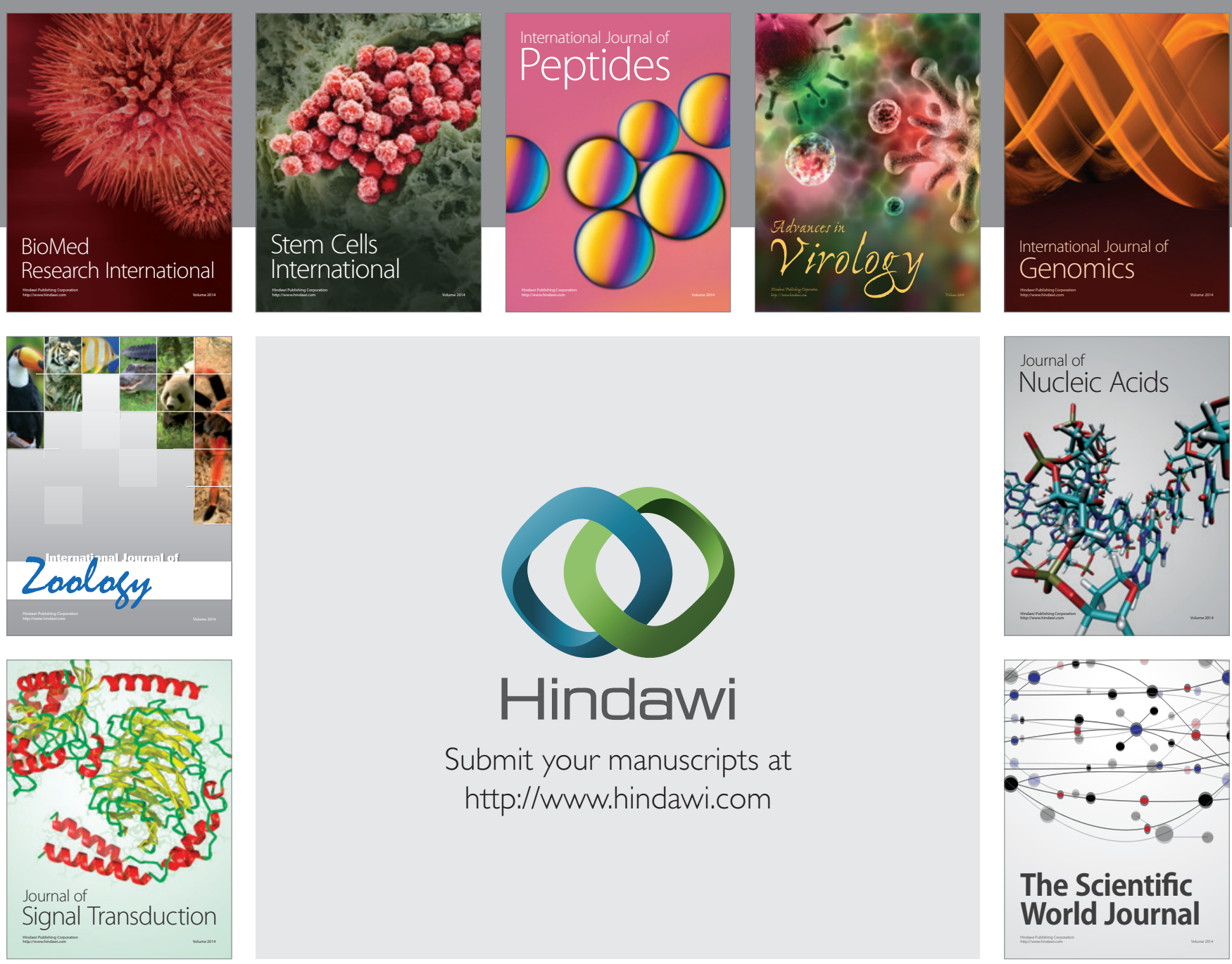

Submit your manuscripts at

http://www.hindawi.com
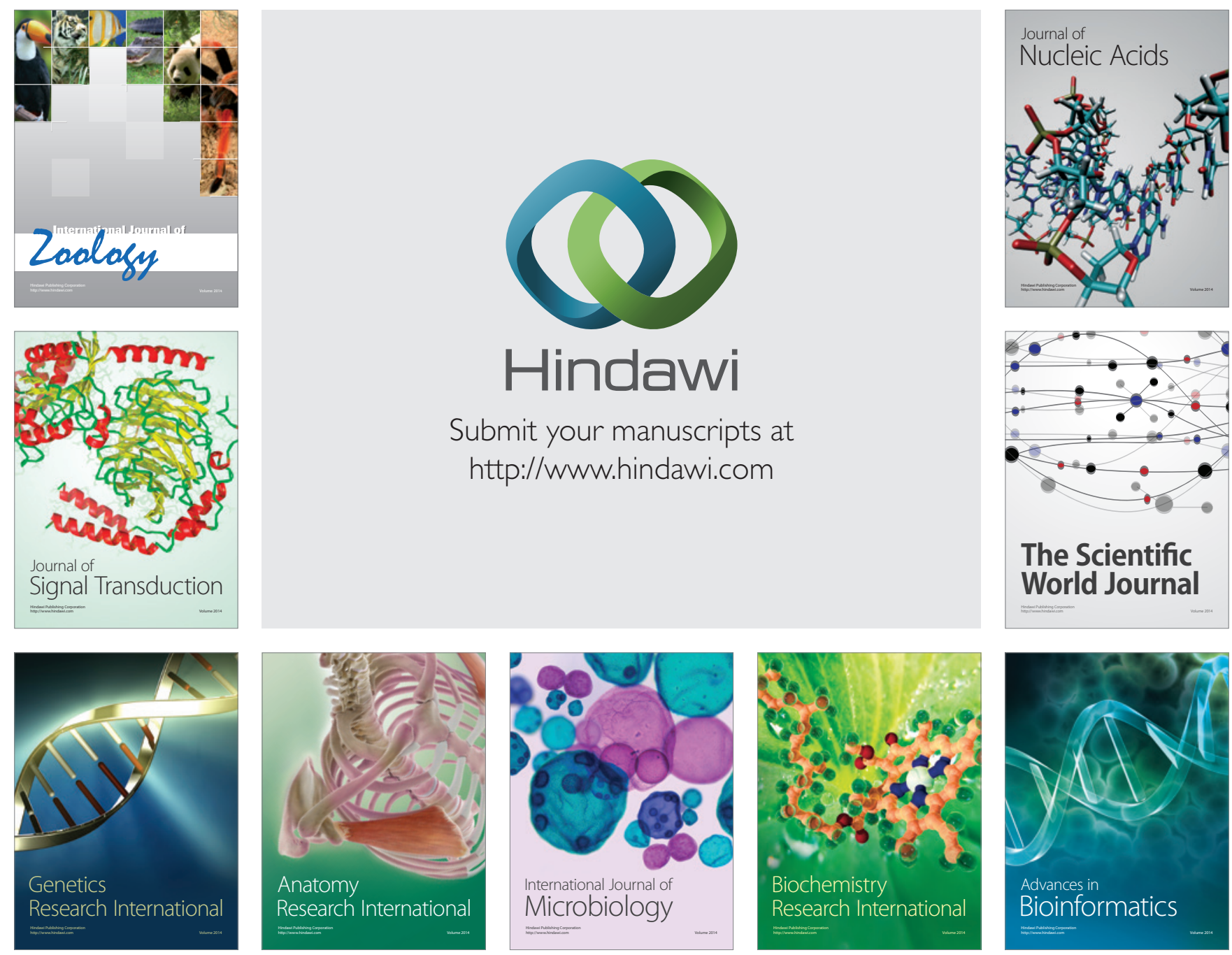

The Scientific World Journal
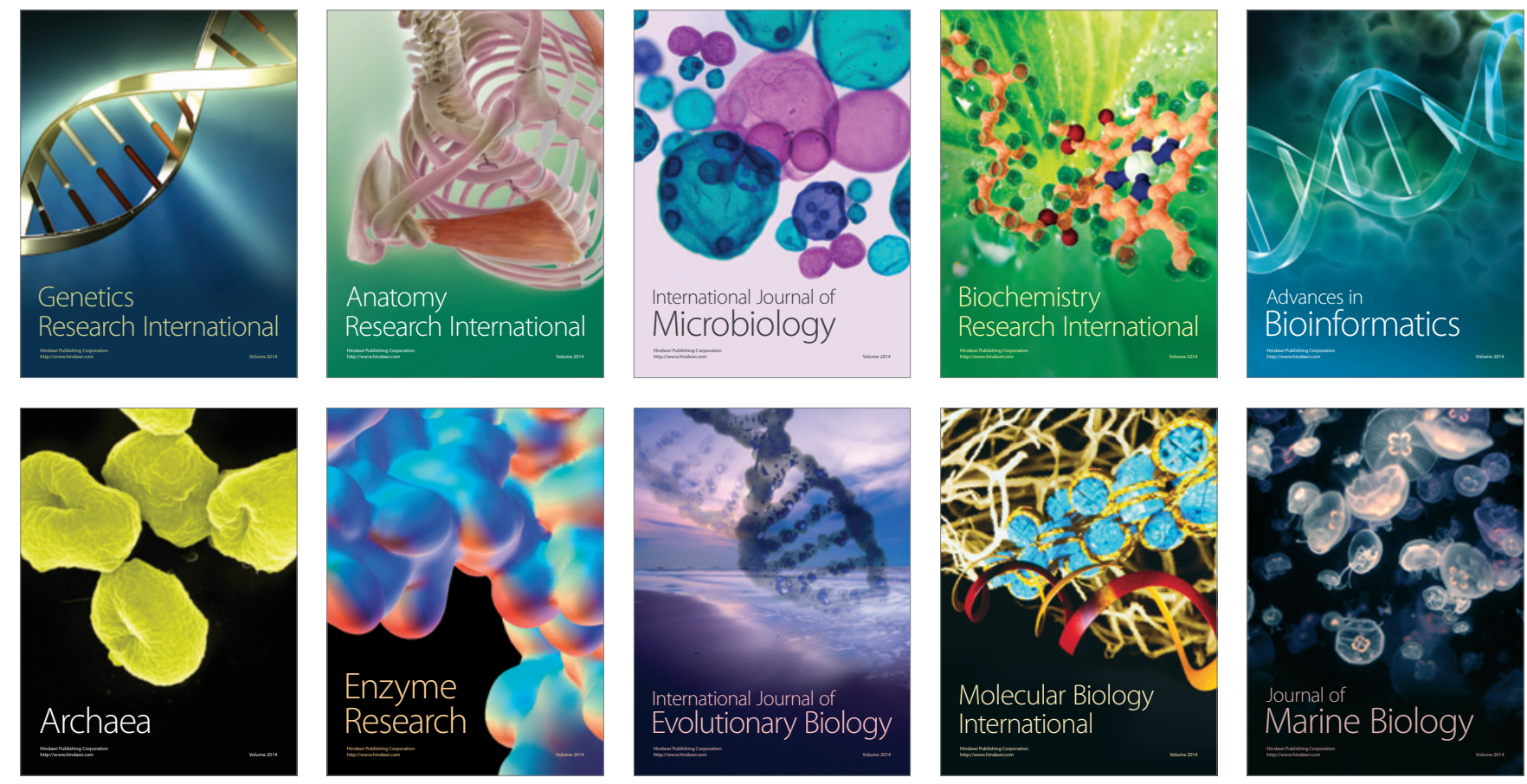